\title{
Ocena zgodności polskiego podatku od wyjścia (exit tax) z prawem unijnym
}

\section{Assessment on the compliance of Polish exit tax with EU law}

Streszczenie. Artykuł dotyczy analizy zgodności polskich regulacji wprowadzających tzw. exit tax, nakładających go na osoby fizyczne - ze swobodą przepływu osób w ramach UE w zakresie natychmiastowego poboru tego podatku. W ramach analizy przywołano orzecznictwo TSUE i zawarte w nim argumenty wskazujące na niedopuszczalność wprowadzania podatku exit tax w kształcie przyjętym w polskich regulacjach.

Słowa kluczowe: osoby fizyczne; podatek od niezrealizowanych zysków; podatek od wyjścia; swobody traktatowe.

\begin{abstract}
The article is focused on an analysis of the compliance of Polish regulations which introduced a so-called "exit tax", which is imposed on natural persons with the free movement of people within the EU in the field of immediate collection of this tax. As a part of the analysis, a reference was made to the case
\end{abstract}


law of the CJEU and the points which it made therein, indicating an inadmissibility of introducing the exit tax, as adopted in Polish regulations.

Keywords: natural persons; tax on unrealized profits; exit tax; the EU treaty freedoms.

\section{Wprowadzenie}

Celem niniejszego artykułu jest ocena zgodności polskich regulacji dotyczących podatku od niezrealizowanych zysków nakładanego w przypadku zmiany rezydencji lub transgranicznego transferu aktywów (tzw. exit tax) ze swobodami traktatowymi.

Cel ten jest uzasadniony ze względu na istnienie rozbieżności pomiędzy prawem unijnym ustanawiającym exit tax a polskimi regulacjami. Wspomniane rozbieżności polegają w szczególności na tym, że na gruncie dyrektywy Rady (UE) 2016/1164 z dnia 12 lipca 2016 r. ${ }^{1}$ wprowadzającej exit tax opodatkowanie dotyczy wyłącznie podatników podatku od osób prawnych. Natomiast w zakresie polskich przepisów opodatkowanie zostało rozszerzone również na osoby fizyczne. Dodatkowo należy zwrócić uwagę, że Trybunał Sprawiedliwości Unii Europejskiej (dalej „TSUE” lub „Trybunał”) wielokrotnie kwestionował takie rozszerzenie (ze względu na konstrukcję spornych przepisów). Przykładem tego może być wyrok TSUE z dnia 11 marca 2004 r. o sygn. C-9/02², w ramach którego uznano, że opodatkowanie wzrostu wartości akcji, w przypadku zmiany rezydencji podatkowej przez osobę fizyczną, narusza traktatową swobodę przedsiębiorczości ${ }^{3}$.

W świetle powyższego można postawić hipotezę mówiącą, że polskie regulacje w zakresie podatku od niezrealizowanych zysków nakłada-

1 Dyrektywa Rady (UE) 2016/1164 z dnia 12 lipca 2016 r. (Dz.Urz. UE L z 2016 r., nr 193, s. 1 ze zm.), dalej: Dyrektywa.

2 Wyrok TSUE z dnia 14 marca 2014 r., C-9/02, https://curia.europa.eu/ (dostęp: 9.12.2020 r.).

3 R. Namysłowski, Opodatkowanie podatkiem dochodowym wzrostu wartości akcji w przypadku zmiany rezydencji podatkowej narusza art. 43 TWE (art. 49 TFUE) wprowadzenie i wyrok TS z 11.03.2004 r. w sprawie C-9/02 Hughes de Lasteyrie du Saiilant v. Ministère de l'Économie, des Finances et de l'Industrie, „Europejski Przegląd Sądowy” 2011, nr 9, s. 49. 
nego na osoby fizyczne są niezgodne z prawem unijnym, a w szczególności ze swobodami traktatowymi.

Aby zweryfikować wymienioną hipotezę, zastosowano metodę dogmatyczno-prawną, przegląd orzecznictwa Trybunału dotyczącego oceny zgodności z normami unijnymi regulacji poszczególnych państw członkowskich dotyczących podatku od niezrealizowanych zysków (nakładanego na osoby fizyczne). Dodatkowo zastosowane metody badawcze zostały uzupełnione o analizę dostępnej literatury naukowej.

\section{Exit tax - zagadnienia ogólne}

Aby przybliżyć istotę podatku od niezrealizowanych zysków kapitałowych, należy wskazać na Dyrektywę wprowadzającą ten podatek. Zgodnie $\mathrm{z}$ nią zadaniem exit tax było zapewnienie, aby w przypadku przeniesienia przez podatnika aktywów lub rezydencji podatkowej poza jurysdykcję danego państwa państwo to mogło opodatkować wartość ekonomiczną ewentualnych zysków kapitałowych osiągniętych na jego terytorium. Zyski będące przedmiotem opodatkowania w chwili dokonania zmiany jurysdykcji podatkowej (lub transgranicznego przeniesienia aktywów) nie stanowią jeszcze zysków zrealizowanych ${ }^{4}$. Zatem exit tax z założenia miał pozwolić państwu rezydencji danego podatnika na opodatkowanie wartości zysków kapitałowych, jakie podatnik mógłby osiągnąć na terytorium tego państwa, gdyby dokonał zbycia aktywów przed zmianą swojej rezydencji podatkowej lub transgranicznym transferem tych aktywów ${ }^{5}$. Skutkiem tego przedmiotem podatku jest tylko hipotetyczny zysk ${ }^{6}$.

Podkreślić należy, że Dyrektywa, wprowadzając exit tax, miała na celu przeciwdziałanie praktykom unikania opodatkowania ${ }^{7}$. Podatek od

\footnotetext{
4 Preambuła do Dyrektywy, pkt 10.

5 A. Mariański, Opodatkowanie fundacji rodzinnych, czyli dokq̨d zmierza tzw. uszczelnianie systemu podatkowego, „Przegląd Podatkowy” 2020, nr 4, s. 35.

6 A. Mariański, Podatek od wyjścia - przykład nieprzemyślanej legislacji podatkowej, „Przegląd Podatkowy” 2019, nr 8, s. 27.

7 H. Litwińczuk, Międzynarodowe prawo podatkowe, Warszawa 2020, LEX/wersja elektroniczna.
} 
wyjścia miał za zadanie chronić interesy państw członkowskich przed przypadkami tzw. sztucznej emigracji, polegającej na przenoszeniu, a następnie zbywaniu aktywów w jurysdykcjach, w których obowiązują preferencyjne warunki opodatkowania takich transakcji (lub w jurysdykcjach nieustanawiających ich opodatkowania) ${ }^{8}$.

Ponadto należy zwrócić szczególną uwagę, że Dyrektywa nakłada na państwa członkowskie obowiązek wprowadzenia przepisów w obszarze opodatkowania exit tax podatników podatku od osób prawnych. Natomiast w Dyrektywie nie zostało uwzględnione opodatkowanie osób fizycznych. Dodatkowo w jej preambule podkreślono, że nie jest wskazane rozszerzanie zakresu opodatkowania na podmioty niepodlegające podatkowi od osób prawnych (choć było to podyktowane względami dotyczącymi trudności z włączeniem do Dyrektywy szerszej gamy podatków krajowych) ${ }^{9}$.

\section{Opodatkowanie exit tax dotyczące osób fizycznych - polskie regulacje}

\subsection{Podstawy prawne exit tax}

Polski prawodawca ustawą z dnia 23 października 2018 r. o zmianie ustawy o podatku dochodowym od osób fizycznych, ustawy o podatku dochodowym od osób prawnych, ustawy - Ordynacja podatkowa oraz niektórych innych ustaw ${ }^{10}$ wprowadził nowy obowiązek podatkowy, dotyczący m.in. osób fizycznych zmieniających miejsce zamieszkania z terytorium Polski na terytorium innego państwa. Obowiązek ten obejmuje również osoby fizyczne transgranicznie transferujące aktywa. Przy-

8 A. Nowak-Piechota, Exit tax: opodatkowanie dochodów z niezrealizowanych zysków w praktyce, 2019, LEX/wersja elektroniczna.

9 Preambuła Dyrektywy, pkt 4.

10 Ustawa z dnia 23 października 2018 r. o zmianie ustawy o podatku dochodowym od osób fizycznych, ustawy o podatku dochodowym od osób prawnych, ustawy - Ordynacja podatkowa oraz niektórych innych ustaw (Dz.U. z 2018 r., poz. 2193). 
toczony podatek został wprowadzony w związku z implementacją Dyrektywy do polskiego porządku prawnego.

\subsection{Konstrukcja polskich regulacji dotyczących opodatkowania osób fizycznych}

Aby dokonać analizy przedstawionego w niniejszym artykule problemu, należy przybliżyć wprowadzoną konstrukcję podatku od niezrealizowanych zysków. Ze względu na zakreślone cele poniżej wskazano wyłącznie na regulacje dotyczące opodatkowania osób fizycznych.

Konstrukcja exit tax została ujęta w art. 30da ustawy z dnia 26 lipca 1991 r. o podatku dochodowym od osób fizycznych ${ }^{11}$. Zgodnie z tym przepisem do opodatkowania dochodzi w następujących przypadkach:

a) przeniesienia składnika majątku poza terytorium Polski, w wyniku którego Polska traci w całości albo w części prawo do opodatkowania dochodów ze zbycia tego składnika majątku, przy czym przenoszony składnik majątku pozostaje własnością tego samego podmiotu;

b) zmiany rezydencji podatkowej przez podatnika podlegającego w Polsce nieograniczonemu obowiązkowi podatkowemu, w wyniku której Polska w całości albo w części traci prawo do opodatkowania dochodów ze zbycia składnika majątku będącego własnością tego podatnika, w związku z przeniesieniem jego miejsca zamieszkania do innego państwa.

Wskazane sytuacje dotyczą składników majątkowych związanych z prowadzeniem działalności gospodarczej przez osoby fizyczne. Natomiast wyjątek stanowią ogół praw i obowiązków w spółce niebędącej osobą prawną udziały, akcje i inne papiery wartościowe, a także pochodne instrumenty finansowe oraz tytuły uczestnictwa w funduszach kapitałowych. Wspomniane typy aktywów mogą podlegać opodatkowaniu bez względu na związek z prowadzoną działalnością gospodarczą (tzw. majątek osobisty).

11 Ustawa z dnia 26 lipca 1991 r. o podatku dochodowym od osób fizycznych (tekst jedn. Dz. U. z 2020 r., poz. 1426 ze zm.), dalej: u.p.d.o.f. 


\subsection{Natychmiastowość poboru podatku exit tax w Polsce}

W ramach oceny zgodności polskich regulacji z prawem unijnym należy zwrócić uwagę na wprowadzony mechanizm tzw. natychmiastowego poboru podatku ${ }^{12}$. Mechanizm ten polega na tym, że w przypadku przeniesienia rezydencji lub transferu majątku poza Polskę podatek staje się należny z chwilą dokonania tego transferu lub przeniesienia rezydencji (podatek jest płatny do 7. dnia kolejnego miesiąca). W ten sposób pobór tego podatku ulega przyśpieszeniu względem sytuacji nietransgranicznych, w ramach których wymagalność miałaby miejsce, gdy zaistniałaby inna czynność skutkująca powstaniem obowiązku podatkowego (w szczególności sprzedaż aktywów).

Niemniej w polskich regulacjach została przewidziana możliwość pośredniego odroczenia płatności podatku ${ }^{13}$, polegająca na rozłożeniu exit tax na raty. Możliwość ta dotyczy sytuacji, w których aktywa lub rezydencja podatkowa jest przenoszona na terytorium państwa członkowskiego Unii Europejskiej (dalej „UE”) lub innego państwa należącego do Europejskiego Obszaru Gospodarczego. Możliwość pośredniego odroczenia płatności podatku jest przyznawana podatnikom na podstawie decyzji wydawanych przez organy podatkowe i może zostać uzależniona od obowiązku złożenia stosownego zabezpieczenia, gwarantującego możliwość ściągnięcia tego podatku ${ }^{14}$.

\section{Potencjalna niezgodność polskich regulacji z prawem unijnym}

Jak wyżej wskazano, w polskich przepisach rozszerzono zakres podatku od wyjścia na osoby fizyczne oraz wprowadzono mechanizm natychmiastowego poboru tego podatku (z uwzględnieniem możliwości jego po-

\footnotetext{
12 A. Nowak-Piechota, Podatek od wyjścia - analiza i ocena regulacji, „Przegląd Podatkowy” 2019, nr 1, s. 36.

13 Tamże, s. 39.

14 Art. 30de u.p.d.o.f.
} 
średniego odroczenia). Biorąc powyższe pod uwagę, można rozważyć, czy wprowadzane regulacje są zgodne z prawem unijnym. Taka analiza jest zasadna ze względu na fakt, że sama konstrukcja podatku od wyjścia może ograniczać podstawowe swobody traktatowe ${ }^{15}$.

Z perspektywy przeprowadzenia analizy zgodności najistotniejsza jest swoboda przepływu osób z art. 21 Traktatu o funkcjonowaniu Unii Europejskiej ${ }^{16}$. Swoboda ta pozwala obywatelom UE przemieszczać się i przebywać na terytorium państw członkowskich, z zastrzeżeniem ograniczeń i warunków ustanowionych w traktatach i środkach przyjętych w celu ich wykonania ${ }^{17}$. Prawo to przysługuje obywatelom państw członkowskich, bez względu na kryteria o charakterze ekonomicznym, będące podstawą do skorzystania z tej swobody ${ }^{18}$.

Powyższa swoboda została rozszerzona w dwóch innych artykułach TfUE, które również zostaną włączone w dokonywane analizy zgodności polskich regulacji z przepisami unijnymi:

a) Art. 45 TfUE - zapewniający swobodę przepływu pracowników wewnątrz UE. Przedmiotowa swoboda dotyczy prawa poruszania się oraz przebywania w jednym z państw członkowskich - w celu zatrudnienia, a także pozostawania w nim po upływie zatrudnienia ${ }^{19}$;

b) Art. 49 TfUE - ustanawiający zakaz ograniczania swobody przedsiębiorczości, obejmującej prawo do podejmowania oraz wykonywania działalności prowadzonej na własny rachunek, w tym również zarządzanie przedsiębiorstwami i ich zakładanie na terenie państw członkowskich ${ }^{20}$.

15 A. Nowak-Piechota, Podatek od wyjścia - analiza..., s. 34.

16 Traktat o funkcjonowaniu Unii Europejskiej (Dz.Urz. UE C 2016, Nr 202, s. 47), dalej: TfUE.

17 K. Kowalik-Bańczyk, Komentarz do art. 21 traktatu o funkcjonowaniu Unii Europejskiej [w:] D. Mąsik, N. Półtorak, A. Wróbel, Komentarz do traktatu o funkcjonowaniu Unii Europejskiej Tom I (art. 1-89), Warszawa 2019, LEX/wersja elektroniczna.

18 D.E. Harasimiuk, Skuteczne korzystanie z prawa pobytu przez obywateli UE i członków ich rodzin, „Ius Novum” 2016, nr 1, s. 63.

19 T. Jurczyk, Prawa jednostki w orzecznictwie Europejskiego Trybunału Sprawiedliwości, Warszawa 2009, LEX/wersja elektroniczna.

20 P.P. Horosz, Swoboda przedsiębiorczości w orzecznictwie Trybunału Sprawiedliwości, „Glosa” 2018, nr 2, s. 21. 


\section{Możliwość ograniczania swobód traktatowych}

\subsection{Zagadnienia ogólne}

Swobody traktowe w zakresie rynku wewnętrznego (np. swoboda przepływu osób) mogą doznać ograniczeń wynikających z regulacji wprowadzanych w porządkach prawnych państw członkowskich UE ${ }^{21}$. Takie ograniczenia mogą być ustanawiane z powołaniem się na derogacje zawarte bezpośrednio w TfUE oraz tzw. wymogi imperatywne, wynikające z orzecznictwa TSUE ${ }^{22}$. Podkreślić należy, że ograniczanie swobód traktatowych wymaga szczegółowego uzasadnienia i podlega rygorystycznym regułom stanowiącym w dużej części dorobek orzecznictwa ${ }^{23}$.

\subsection{Możliwe uzasadnienia dla naruszania swobód traktatowych}

Na gruncie dostępnej literatury ocena, czy dana regulacja ograniczająca swobody traktatowe jest odpowiednio uzasadniona, jest dokonywana na podstawie derogacji dotyczących podatkowych względów interesu ogólnego, do których mogą zaliczać się m.in.: spójność systemów podatkowych państw członkowskich, zrównoważony podział kompetencji podatkowych między państwami UE, przeciwdziałanie unikaniu opodatkowania i uchylaniu się od niego, skuteczność kontroli podatkowych, zmniejszenie dochodów budżetowych ${ }^{24}$ lub zasada terytorialności ${ }^{25}$.

Niemniej argumenty uzasadniające naruszenie swobody traktatowej w dużej mierze wynikają z orzecznictwa TSUE. Na gruncie samego opodatkowania niezrealizowanych zysków linia orzecznicza dotycząca tego

21 A. Frąckowiak-Adamska, Zasada proporcjonalności jako gwarancja swobód rynku wewnętrznego Wspólnoty Europejskiej, Warszawa 2009, LEX/wersja elektroniczna.

22 J. Maliszewska-Nienartowicz, Sqqdowe stosowanie wspólnotowej zasady proporcjonalności, „Europejski Przegląd Sądowy” 2009, nr 1, s. 13.

23 A. Cieśliński, Konstrukcja prawna swobód rynku wewnętrznego Unii Europejskiej, Wrocław 2013, s. 206.

24 Tamże, s. 97-98.

25 R. Lipniewicz, Podatkowa zasada terytorialności w kontekście rynku wewnętrznego UE, „Europejski Przegląd Sądowy” 2013, nr 4, s. 40. 
zagadnienia ma utrwaloną i bogatą historię, kształtującą się już od lat 90. XX w.

Przykładem orzeczenia podejmującego oznaczoną kwestię może być wyrok Trybunału z dnia 28 stycznia 1992 r. o sygn. C-300/90 dotyczący braku możliwości potrącenia składek ubezpieczeniowych od dochodu, gdy składki te są płacone do zagranicznych zakładów ubezpieczeniowych. W ramach tego orzeczenia przyznano, że konieczność ochrony spójności systemu podatkowego może uzasadniać ograniczenie wykonywania swobód zagwarantowanych przez traktat ${ }^{26}$. Argumentacja Trybunału w wyżej wymienionym orzeczeniu bazowała na założeniu, że zachodzi niemożność zachowania gwarancji w przypadku odliczenia składek płaconych do zagranicznych zakładów ubezpieczeniowych do zrównoważenia ich przez późniejsze opodatkowanie wypłat świadczeń ubezpieczeniowych ${ }^{27}$. Trybunał uznał, że tylko, gdy zachodzi bezpośredni związek pomiędzy obciążeniem podatkowym a następującą po nim korzyścią finansową, możliwe jest dopuszczenie uzasadnienia w zakresie ochrony spójności systemu podatkowego $^{28}$. Także w wyroku Trybunału z dnia 28 stycznia 1992 r. o sygn. sygn. C-204/90²9 uznano, że argument ochrony spójności podatkowej państwa członkowskiego może stanowić uzasadnienie ograniczenia swobód traktatowych ${ }^{30}$ (rozpatrywana sprawa była analogiczna do wskazanej powyżej).

Niekiedy wyżej przytoczone cele na gruncie opodatkowania podatkiem od niezrealizowanych zysków były uznawane przez Trybunał za niewystarczające. Na przykład argumentowano, że przeciwdziałanie obej-

26 Wyrok TSUE z dnia 28 stycznia 1992 r., C-300/90, akapit 21, https://curia.europa.eu/ (dostęp: 9.12.2020 r.).

27 A. Jerzykowski, Glosa do wyroku TS z dnia 28 stycznia 1992 r., C-300/90 [w:] W. Nykiel, A. Zalasiński, Orzecznictwo Trybunału Sprawiedliwości Unii Europejskiej w sprawach podatkowych. Komentarz, Warszawa 2014, s. 100.

28 I. Angelova, Justifications for restricting fundamental freedoms accepted by the European Court of Justice, „The EC Tax Journal” 2011, t. 12, s. 104.

29 Wyrok TSUE z dnia 28 stycznia 1992 r., C-204/90, https://curia.europa.eu/ (dostęp: 9.12.2020 r.).

30 A. Jerzykowski, Glosa do wyroku TS z dnia 28 stycznia 1992 r., C-204/90 [w:] W. Nykiel, A. Zalasiński, Orzecznictwo Trybunału Sprawiedliwości Unii Europejskiej w sprawach podatkowych. Komentarz, Warszawa 2014, s. 86. 
ściu prawa nie stanowi wystarczającego uzasadnienia dla państwa członkowskiego do wprowadzenia przepisów ograniczających swobody traktatowe, jeżeli tymi przepisami objęte są wszystkie osoby, bez względu na istnienie obiektywnych intencji dotyczących zmiany rezydencji ${ }^{31}$. Ponadto Trybunał stwierdził, że uszczuplenie wpływów podatkowych danego państwa członkowskiego nie może być traktowane jako nadrzędny interes publiczny ${ }^{32}$.

W ostatnich latach w ramach swojej praktyki orzeczniczej Trybunał doszedł do konkluzji, że państwa członkowskie w celu ustanowienia podatku od wyjścia mogą powoływać się na skuteczny nadzór podatkowy, podział kompetencji podatkowych (w tym zasadę terytorialności) i ochronę spójności systemu podatkowego ${ }^{33}$.

\subsection{Zasada proporcjonalności}

W celu uznania danych regulacji naruszających swobody traktatowe za zgodne z prawem unijnym nie jest wystarczającym, aby były one należycie uzasadnione określnym celem. Oprócz tego kryterium dane naruszenie musi spełniać również test proporcjonalności.

Zatem należy przytoczyć, iż na gruncie swobody przepływu osób w literaturze wskazuje się, że może ona doznać ograniczeń, jeśli te ograniczenia są proporcjonalne do uzasadnionego celu realizowanego przez ustanowione przepisy państwa członkowskiego ${ }^{34}$. W szczególności oznacza to, że zastosowany środek prawny ograniczający swobody traktatowe powinien być rzeczywiście niezbędny do osiągnięcia założonego przez określone regulacje celu oraz istnieje niemożność zastosowania mniej dolegliwych narzędzi służących do realizacji tego celu ${ }^{35}$.

31 Wyrok TSUE z dnia 14 marca 2014 r., C-9/02, akapit 68, https://curia.europa.eu/ (dostęp: 9.12.2020 r.).

32 Tamże, akapit 60, https://curia.europa.eu/ (dostęp: 9.12.2020 r.).

33 A. Nowak-Piechota, Podatek od wyjścia, Łódź 2018, s. 125-130.

34 A. Frąckowiak-Adamska, O istocie praw wynikajacych z obywatelstwa Unii, „Europejski Przegląd Sądowy” 2012, nr 10, s. 22.

35 R. Lipniewicz, Zasada proporcjonalności a podatkowe ograniczenia swobód rynku wewnętrznego Unii Europejskiej, „Ruch Prawniczy, Ekonomiczny i Socjologiczny” 2015, nr 4, s. 98. 
Powyższe było podkreślane w orzecznictwie Trybunału, w wyrokach zapadłych w ostatnich latach (np. wyroki Trybunału z dnia 21 grudnia 2016 r. o sygn. C-503/14 ${ }^{36}$ oraz z dnia 26 lutego 2019 r. o sygn. C-581/17 $7^{37}$ ). W ramach przytoczonych orzeczeń wskazywano, że regulacje dotyczące podatku od niezrealizowanych zysków muszą spełniać zasadę proporcjonalności ${ }^{38}$. Na podstawie tej zasady Trybunał w obu przytoczonych wyrokach uznał, że sporne przepisy nie pozostają w zgodzie z prawem unijnym (tj. nie są odpowiednie do osiągnięcia założonego celu i wykraczają poza to, co niezbędne do jego osiągnięcia) ${ }^{39}$.

\section{Polskie regulacje a swobody traktatowe}

Analizując polskie przepisy w zakresie ich zgodności z prawem unijnym, w pierwszej kolejności należy zweryfikować, czy różnicują one sytuację osób przenoszących miejsce zamieszkania do innego państwa UE (lub transferujących aktywa poza Polskę) i osób pozostających w warunkach krajowych, prowadząc do sytuacji, w której tworzy się mniej korzystną sytuację dla przypadków transgranicznych.

Odnosząc się do powyższego, należy podkreślić, że w Polsce przyjęto konstrukcje przyśpieszonego poboru podatku w stosunku do osób zmieniających swoje miejsce zamieszkania na inne państwo (lub dokonujących transgranicznego transferu aktywów). Oznacza to, że takie osoby muszą uiścić podatek wcześniej, niż zaistnieje czynność tworząca ten obowiązek w warunkach krajowych. Prowadzi to do sytuacji, w której osoby przenoszące miejsce zamieszkania (lub transgranicznie transferują-

36 Wyrok TSUE z dnia 21 grudnia 2016 r., C-503/14, https://curia.europa.eu/ (dostęp: 9.12.2020 r.).

37 Wyrok TSUE z dnia 26 lutego 2019 r., C-581/17, https://curia.europa.eu/ (dostęp: 9.12.2020 r.).

38 W sprawie C-581/17, w ocenie Trybunału, środek w postaci odroczenia płatności podatku do chwili zbycia tych udziałów byłby mniej uciążliwy - zob. E. Prejs, Zmiana miejsca zamieszkania z państwa członkowskiego UE do Konfederacji Szwajcarii a exit tax. Omówienie do wyroku TS z dnia 26 lutego 2019 r., C-581/17, „Przegląd Podatkowy" 2019, nr 5, s. 57.

39 Wyrok TSUE z dnia 26 lutego 2019 r., akapit 63; wyrok TSUE z dnia 21 grudnia 2016 r., C-503/14, akapit 90, https://curia.europa.eu/ (dostęp: 9.12.2020 r.). 
ce aktywa) tracą możliwość dysponowania środkami pieniężnymi w okresie przypadającym pomiędzy momentem zmiany miejsca zamieszkania (lub transferu aktywów) a zaistnieniem czynności, która w warunkach krajowych powodowałaby powstanie obowiązku podatkowego. Tym samym zmiana miejsca zamieszkania/transgraniczny transfer aktywów prowadzi do powstania niekorzystnego efektu finansowego.

Trybunał w swoim orzecznictwie podkreślał, że za ograniczenia swobodnego przepływu osób (w tym pracowników) i swobody przedsiębiorczości należy uznać nie tylko wszelkie przepisy, które uniemożliwiają korzystanie z tych swobód, ale również te przepisy, które jedynie utrudniają wspomniane korzystanie lub ograniczają jego atrakcyjność ${ }^{40}$. Pogląd ten jest przytaczany i aprobowany w literaturze przedmiotu ${ }^{41}$. Natomiast polskie regulacje kształtują sytuację podatnika w taki sposób, że w celu uniknięcia negatywnego efektu finansowego korzystniejszym staje się operowanie w warunkach nietransgranicznych - tym samym zmniejszają one atrakcyjność swobód traktatowych.

W zakresie samych celów realizowanych przedmiotowymi regulacjami Trybunał, jak wyżej wskazano, dopuścił argumenty przemawiające za możliwością opodatkowania niezrealizowanych zysków ${ }^{42}$. Takie stanowisko jest uzasadnione przez zastosowanie zasady szczególnych powodów, zgodnie z którą, w ograniczonych przypadkach, przez wzgląd na potrzebę ochrony istotnych wartości, działania ograniczające swobody traktatowe mogą być usprawiedliwione ${ }^{43}$. Wydaje się, że w kwestii podatku od wyjścia za dopuszczalne należy uznać uzasadnienie tego opodatkowania przez zabezpieczenie uprawnienia do opodatkowania zysków przez państwo członkowskie, które powstały na jego terytorium. Dodatkowo

40 E. Prejs, Dyskryminujqce skutki zmiany rezydencji podatkowej oraz przeniesienia majątku przypisanego do działalności gospodarczej w podatku dochodowym od osób fizycznych. Omówienie do wyroku TS z dnia 21 grudnia 2016 r., C-503/14, „Przegląd Podatkowy” 2017, nr 2, s. 55.

41 A. Mariański, Podatek od wyjścia..., s. 24.

42 A. Nowak-Piechota, Podatek od wyjścia..., s. 125-130.

43 B. Brzeziński, Zasada niedyskryminacji w europejskim prawie podatkowym. Sprawa Gilly i aktualne kierunki orzecznictwa Europejskiego Trybunału Sprawiedliwości [w:] A. Olesińska (red.), Europejskie Prawo Podatkowe. Wybór opracowań, Łódź 2004, s. 77. 
wskazać należy, że podatek ten stanowi narzędzie mające za zadanie ochronę przed nadużyciami podatkowymi (w szczególności przed zjawiskiem sztucznej emigracji).

Niemniej Trybunał wielokrotnie stwierdzał, że natychmiastowy pobór nie jest zgodny z zasadą proporcjonalności. Co wydaje się zasadne, zważywszy na fakt, że istnieją środki mniej uciążliwe, a realizujące założone cele - to jednoznacznie wskazuje, że sam natychmiastowy pobór podatku nie może przejść testu proporcjonalności.

Jak już wyżej wskazano, w zakresie analizowanych regulacji zdecydowano się na dodatkowy model pośredniego odroczenia zapłaty podatku. Jednak zastosowanie tego modelu jest zależne od decyzji organu podatkowego i może być obarczone obowiązkiem złożenia zabezpieczenia (gdy istnieje realne ryzyko nieodzyskania przedmiotowego podatku) ${ }^{44}$. Natomiast na gruncie w orzecznictwie TSUE podkreślano, że odroczenie podatku powinno być uzależnione od wyboru podatnika ${ }^{45}$. Takie poglądy przytaczano także w innych publikacjach naukowych ${ }^{46}$, jednoznacznie wskazując na niezgodność przyjętej w Polsce konstrukcji z prawem unijnym ${ }^{47}$.

Podkreślić należy, że konstrukcja pośredniego odroczenia w przypadku opodatkowania osób fizycznych została już zakwestionowana w orzecznictwie Trybunału (np. w wyroku z dnia 26 lutego 2019 r. o sygn. C-581/17) jako niewystarczająca do uznania, że zasada proporcjonalności jest spełniona ${ }^{48}$. Ponadto w wyroku Trybunału z dnia 7 września 2006 o sygn. C-470/04 stwierdzono, że w przypadku opodatkowania osób fizycznych podatkiem od niezrealizowanych zysków nieuprawnione jest

\footnotetext{
Art. 30de u.p.d.o.f.

45 Wyrok TSUE z dnia 21 maja 2015 r., C-657/13, akapit 49, https://curia.europa.eu/ (dostęp: 9.12.2020 r.).

46 J. Koronkiewicz, Aktywność UE w odpowiedzi na projekt BEPS [w:] B. Brzeziński, K. Lasiński-Sulecki, W. Morawski, D. Gibasiewicz, P. Karwat, J. Koronkiewicz, A. Ladziński, D. Mączyński, P. Mikuła, A. Olesińska, A. Podsiadły, J. Zawiejska-Rataj, A. Zdunek, Nowe narzędzia kontrolne, dokumentacyjne i informatyczne w prawie podatkowym, Warszawa 2018, s. 45.

47 K. Suchojda, Podatek od niezrealizowanych zysków - modelowa koncepcja a rozwiqzania polskie, „Monitor Podatkowy” 2019, nr 1, s. 31.

48 Wyrok TSUE z dnia 26 lutego 2019 r., C-581/17, akapit 68, https://curia.europa.eu/ (dostęp: 9.12.2020 r.).
} 
wprowadzanie obowiązku ustanowienia zabezpieczenia w celu skorzystania z odroczenia jego płatności (co natomiast jest możliwe w polskiej konstrukcji exit tax). Powyższe podejście Trybunału wydaje się uzasadnione zasadą proporcjonalności, której nie realizują wyżej wymienione konstrukcje.

W świetle przytoczonej powyżej argumentacji możliwe jest zabezpieczenie poboru podatku przez Polskę z wykorzystaniem narzędzi bardziej dogodnych dla podatnika niż wprowadzona konstrukcja natychmiastowego poboru ze względną możliwością rozłożenia go na raty.

Wydaje się, że mechanizmem (w przypadku opodatkowania osób fizycznych), który byłby w zgodzie z zasadą proporcjonalności, jest odroczenie płatności podatku, nieobarczone warunkiem złożenia przez podatnika odpowiedniej gwarancji lub poręczenia i przyznawane automatycznie, a nie jak w przypadku polskich regulacji - na podstawie decyzji organu podatkowego. Takie stanowisko przyjął także Trybunał, według którego w przypadku opodatkowania występującego w związku ze zmianą rezydencji takie opodatkowanie jest możliwe, jeżeli pobór podatku nie jest natychmiastowy, a jest dokonywany z odroczeniem płatności nieobarczonym żadnymi warunkami ${ }^{49}$.

Przytoczona konstrukcja byłaby najmniej uciążliwa dla podatnika, a jednocześnie nie stałaby na przeszkodzie realizacji celu zabezpieczenia interesów fiskalnych Polski. Mechanizm ten nadal spełniałaby funkcję ochronną w zakresie praktyk mających na celu unikanie opodatkowania. Chroniłby przed nieuczciwymi praktykami polegającymi na tymczasowej zmianie rezydencji w celu sprzedaży aktywów w preferencyjnych podatkowo jurysdykcjach.

\section{Konkluzje}

Biorąc pod uwagę powyższe rozważania, można przedstawić kilka kluczowych wniosków w zakresie analizy zgodności podatku od niezreali-

49 Wyrok TSUE z dnia 7 września 2006 r., C-470/04, akapit 66, https://curia.europa.eu/ (dostęp: 9.12.2020 r.). 
zowanych zysków ze swobodami unijnymi. Po pierwsze, należy zaznaczyć, że same swobody traktatowe mogą doznawać ograniczeń. Jednak jest to możliwe pod pewnymi warunkami. W szczególności w orzecznictwie oraz w literaturze został postawiony wymóg, aby te ograniczenia były należycie uzasadnione. W tym zakresie wskazuje się, że akceptowanymi argumentami są potrzeba zachowania skutecznego nadzoru podatkowego, podział kompetencji podatkowych (w tym zasada terytorialności) i ochrona spójności systemów podatkowych państw członkowskich. Wobec powyższego na bazie aktualnego orzecznictwa TSUE dopuszcza się możliwość nakładania podatku od niezrealizowanych zysków na osoby fizyczne. Wydaje się to uzasadnione - biorąc pod uwagę zadania realizowane poprzez wprowadzenie exit tax (tj. cele tych regulacji).

Kolejnym kluczowym wnioskiem jest fakt, iż obecnie jednym z najważniejszych kryteriów dla oceny zgodności analizowanego podatku z prawem unijnym jest spełnienie zasady proporcjonalności. Wydaje się to szczególnie uzasadnione ze względu na wyroki TSUE zapadłe w ostatnich latach. W tych wyrokach Trybunał, na jej podstawie, kwestionował zgodność konstrukcji exit tax wprowadzonych w innych państwach członkowskich, argumentując, że dla realizacji ich celów można zastosować środki mniej uciążliwe dla podatników. Dlatego też, analizując polskie przepisy, należy zwrócić uwagę na wspomnianą zasadę.

W tym świetle, aby ocenić zgodność wprowadzonych w Polsce przepisów ze swobodami traktatowymi, koniecznym jest dokonanie analizy, czy zastosowane mechanizmy stanowią konstrukcję najmniej uciążliwą ze wszystkich możliwych rozwiązań realizujących uzasadnione cele exit tax. W tym zakresie należy wziąć pod uwagę fakt, że wdrożone regulacje zostały połączone z zastosowaniem natychmiastowej wymagalności podatku (z opcją pośredniego odroczenia). Natomiast odnosząc się do celów exit tax, wskazane jest podkreślenie, że mogą one być realizowane przy wprowadzeniu możliwości automatycznego odraczania płatności podatku (nieobarczonego dodatkowymi wymogami). Powyższe prowadzi do wniosku stanowiącego, że w przypadku analizowanych przepisów nie dochodzi do spełnienia zasady proporcjonalności. Z tego względu polskie regu- 
lacje nakładające podatek od niezrealizowanych zysków na osoby fizyczne należy uznać za niezgodne z prawem unijnym.

\section{Bibliografia:}

Angelova I., Justifications for restricting fundamental freedoms accepted by the European Court of Justice, „The EC Tax Journal” 2011, t. 12, s. 99-116.

Brzeziński B., Zasada niedyskryminacji w europejskim prawie podatkowym. Sprawa Gilly i aktualne kierunki orzecznictwa Europejskiego Trybunału Sprawiedliwości, [w:] A. Olesińska (red.), Europejskie Prawo Podatkowe. Wybór opracowań, Fundacja Centrum Dokumentacji i Studiów Podatkowych, Łódź 2004, s. 65-94.

Cieśliński A., Konstrukcja prawna swobód rynku wewnętrznego Unii Europejskiej, Prawnicza i Ekonomiczna Biblioteka Cyfrowa, Wrocław 2013.

Frąckowiak-Adamska A., O istocie praw wynikajqcych z obywatelstwa Unii, „Europejski Przegląd Sądowy” 2012, nr 10, s. 21-33.

Frąckowiak-Adamska A., Zasada proporcjonalności jako gwarancja swobód rynku wewnętrznego Wspólnoty Europejskiej, Warszawa 2009, LEX/wersja elektroniczna.

Harasimiuk D.E., Skuteczne korzystanie z prawa pobytu przez obywateli UE i członków ich rodzin, „Ius Novum” 2016, nr 1, s. 63-78.

Horosz P.P., Swoboda przedsiębiorczości w orzecznictwie Trybunału Sprawiedliwości, „Glosa” 2018, nr 2, s. 19-26.

Jerzykowski A., Glosa do wyroku TS z dnia 28 stycznia 1992 r., C-204/90, [w:] W. Nykiel, A. Zalasiński, Orzecznictwo Trybunału Sprawiedliwości Unii Europejskiej w sprawach podatkowych. Komentarz, Warszawa 2014, s. 80-93.

Jerzykowski A., Glosa do wyroku TS z dnia 28 stycznia 1992 r., C-300/90, [w:] W. Nykiel, A. Zalasiński, Orzecznictwo Trybunału Sprawiedliwości Unii Europejskiej w sprawach podatkowych. Komentarz, WK 2014, s. 94-105.

Jurczyk T., Prawa jednostki w orzecznictwie Europejskiego Trybunału Sprawiedliwości, Warszawa 2009, LEX/wersja elektroniczna.

Koronkiewicz J., Aktywność UE w odpowiedzi na projekt BEPS [w:] B. Brzeziński, K. Lasiński-Sulecki, W. Morawski, D. Gibasiewicz, P. Karwat, J. Koronkiewicz, A. Ladziński, D. Mączyński, P. Mikuła, A. Olesińska, A. Podsiadły, J. Zawiejska-Rataj, A. Zdunek, Nowe narzędzia kontrolne, dokumentacyjne i informatyczne w prawie podatkowym, Warszawa 2018, s. 31-120. 
Kowalik-Bańczyk K., Komentarz do art. 21 traktatu o funkcjonowaniu Unii Europejskiej [w:] D. Mąsik, N. Półtorak, A. Wróbel, Komentarz do traktatu o funkcjonowaniu Unii Europejskiej Tom I (art. 1-89), Warszawa 2019, LEX/wersja elektroniczna.

Lipniewicz R., Podatkowa zasada terytorialności w kontekście rynku wewnętrznego UE, „Europejski Przegląd Sądowy” 2013, nr 4, s. 37-42.

Lipniewicz R., Zasada proporcjonalności a podatkowe ograniczenia swobód rynku wewnętrznego Unii Europejskiej, „Ruch Prawniczy, Ekonomiczny i Socjologiczny” 2015, nr 4, s. 93-103.

Litwińczuk H., Międzynarodowe prawo podatkowe, Warszawa 2020, LEX/wersja elektroniczna.

Maliszewska-Nienartowicz J., Sqqdowe stosowanie wspólnotowej zasady proporcjonalności, „Europejski Przegląd Sądowy” 2009, nr 1, s. 11-17.

Mariański A., Opodatkowanie fundacji rodzinnych, czyli dokq̨d zmierza tzw. uszczelnianie systemu podatkowego, „Przegląd Podatkowy” 2020, nr 4, s. 32-40.

Mariański A., Podatek od wyjścia - przykład nieprzemyślanej legislacji podatkowej, „Przegląd Podatkowy” 2019, nr 8, s. 21-30.

Namysłowski R., Opodatkowanie podatkiem dochodowym wzrostu wartości akcji w przypadku zmiany rezydencji podatkowej narusza art. 43 TWE (art. 49 TFUE) - wprowadzenie i wyrok TS z 11.03.2004 r. w sprawie C-9/02 Hughes de Lasteyrie du Saiilant v. Ministère de l'Économie, des Finances et de l'Industrie, „Europejski Przegląd Sądowy” 2011, nr 9, s. 48-54.

Nowak-Piechota A., Exit tax: opodatkowanie dochodów z niezrealizowanych zysków w praktyce, 2019, LEX/wersja elektroniczna.

Nowak-Piechota A., Podatek od wyjścia, Wydawnictwo Uniwersytetu Łódzkiego, Łódź 2018.

Nowak-Piechota A., Podatek od wyjścia - analiza i ocena regulacji, „Przegląd Podatkowy” 2019, nr 1, s. 34-40.

Prejs E., Dyskryminujące skutki zmiany rezydencji podatkowej oraz przeniesienia majątku przypisanego do działalności gospodarczej w podatku dochodowym od osób fizycznych. Omówienie do wyroku TS z dnia 21 grudnia 2016 r., C-503/14, „Przegląd Podatkowy” 2017, nr 2, s. 54-57.

Prejs E., Zmiana miejsca zamieszkania z państwa członkowskiego UE do Konfederacji Szwajcarii a exit tax. Omówienie do wyroku TS z dnia 26 lutego 2019 r., C-581/17, „Przegląd Podatkowy” 2019, nr 5, s. 56-57.

Suchojda K., Podatek od niezrealizowanych zysków - modelowa koncepcja a rozwiqzania polskie, „Monitor Podatkowy” 2019, nr 1, s. 27-33. 